\title{
Family-Based Teacher Character Education Trial In Efforts To Prevent Male Sexual Behavior In The Plantation Area Of Jember District
}

\author{
Iis Rahmawati ${ }^{*}$, Dewi Rokhmah ${ }^{2}$ \\ ${ }^{1}$ Department of Maternity and Child Nursing, Faculty of Nursing, University of Jember \\ ${ }^{2}$ Health Promotion Department, Faculty of Public Health, University of Jember \\ *email : rahmawati.psik@gmail.com
}

\begin{abstract}
Background. Premarital sexual behavior among adolescents tends to increase. There has been an increase in cases of premarital sexual behavior among adolescents in Jember, namely 47 cases in 2015 and 52 cases in 2016 and cases for the period JanuaryMarch 2017, data obtained from the Jember Police were 17 cases of premarital sexual behavior by adolescents, so they need to be handled early through the prevention of premarital sexual behavior by adolescents. The purpose of this study is a continuation of the research results of the research dissertation with the findings of a family-based youth character education model in the prevention of premarital sexual behavior, it is necessary to test the model that has been produced in rural areas in the prevention of premarital sexual behavior. This research method used experimental design (pre-experiment) with a one group pretest-postest design. The research was conducted in collaboration with schools in rural areas of Jember Regency in preparing all resources to conduct model trials with training activities for adolescents. The results showed that the training of adolescent character education models significantly ( $\mathrm{sig}=0,000$ ) was able to increase knowledge of adolescent personalities, was able to increase adolescent morality (sig $=0.002$ ), was able to increase the prevention of premarital sexual behavior ( $\mathrm{sig}=0.006)$. Conclusion: model trials in rural areas by conducting youth character education model training can increase adolescent personal knowledge, adolescent morality and prevention of premarital sexual behavior. and next it is suggested to try out the youth character education model in urban areas in Jember Regency.
\end{abstract}

Keyword:

Premarital sexual behavior, adolescents, prevention of premarital sexual behavior.

Article Received: 18 October 2020, Revised: 3 November 2020, Accepted: 24 December 2020

\section{Introduction}

The National Family Planning Coordination Body (BKKBN) in 2013 stated that as many as $4.38 \%$ of adolescents aged $10-14$ years had engaged in casual sex activities, while adolescents aged $14-19$ were $41.8 \%$. According to the records of the National Commission for Child Protection, there was an increase in abortion, from 86 cases in 2011 to 121 cases in 2012. Of these cases, 8 people died. Previous research conducted by Susanto, et al (2014) on 116 high school respondents aged 16-19 years in Jember Regency showed that $65 \%$ of adolescents already have boyfriends and as many as $63 \%$ have had sexual intercourse, in the form of kissing while dating and $23 \%$ did petting and $8 \%$ had sexual intercourse.

Based on these problems, it will cause various health problems in adolescents, so that it will increasingly place adolescents as part of the population at risk in society from the aspect of adolescent reproductive health, namely premarital sexual behavior. Premarital sexual behavior in adolescents is behavior due to sexual urges committed by the opposite sex and not officially bound by marriage. The maturity of the reproductive organs that is reached during adolescence allows adolescents to have curiosity and an urge to engage in inappropriate sexual behavior.

According to data from the World Health Organization (WHO) around the world, an estimated 15 million adolescents are pregnant each year, $60 \%$ of whom are pregnant outside of marriage, as many as 560 cases (10.89\%). Unmarried pregnancies throughout 2004 occurred in the 18 year age group or high school education age group. If seen from the proportion of those who experienced pregnancy outside of marriage, it is 
divided into junior high school education (SMP) as much as $14.2 \%$ and the proportion of high school education level (SMA) is $16.8 \%$, the rest (4\%) is a group of students . Most of the out-of-wedlock pregnant adolescents are in the age range 15-24 years and adolescent knowledge about the risks of sexual intercourse is still low (Depkes R.I, 2000).
Data from the Office of Religious Affairs (KUA) in Jember Regency that those who applied for marriage dispensation ranged in age from 16-19 years as many as 158 couples due to pregnancy outside of marriage (KUA Jember, 2016). Data on immoral acts as part of adolescent premarital sexual behavior from the Jember Regional Police can be seen in Graph 1.1 below.

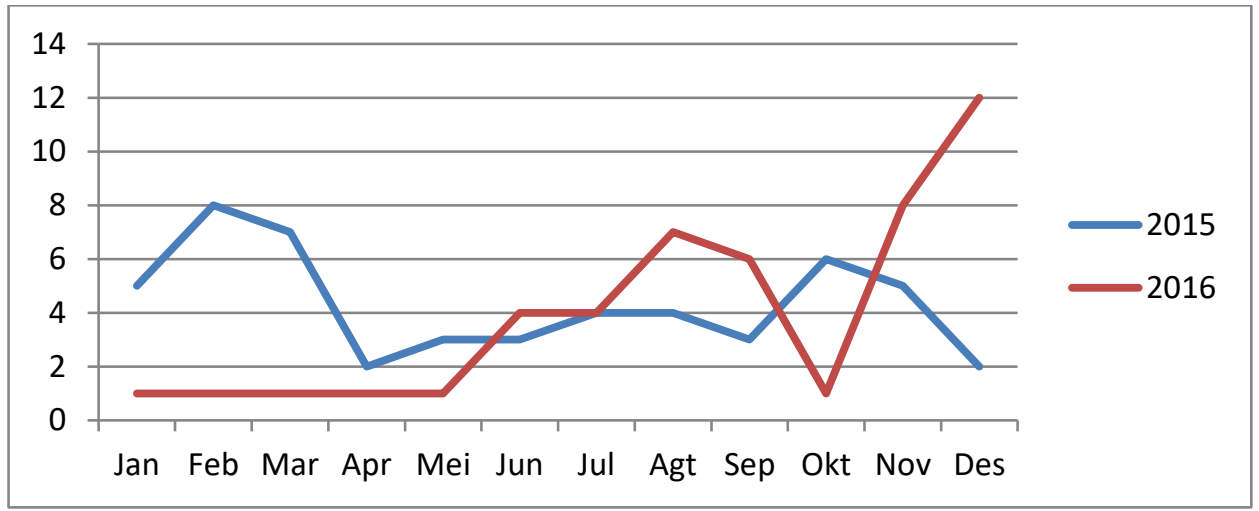

Source: PPA Polres Jember, 2017

Graph 1. Incidence of Adolescent Premarital Sexual Behavior in Jember 2015-2016

Based on Figure 1, it shows that adolescent sexual cases in Jember have increased, amounting to 47 cases in 2015 and 52 cases in 2016. The cases of premarital sexual behavior among adolescents include sexual harassment, promiscuity, and escaping underage children. The case of premarital sexual behavior in adolescents is like an iceberg phenomenon that can be seen on the surface. The incidence of premarital sexual behavior in Jember is quite high. Immoral data for the period JanuaryMarch 2017 from the Jember Police were 17 immoral cases by teenagers (PPA Polres Jember, 2017).

The risky sexual behavior of adolescents reflects the lack of information on reproductive health, which is part of adolescent character education to prevent premarital sexual behavior. Knowledge about sexuality and reproductive health between adolescents living in rural areas and adolescents living in urban areas is certainly different. This is due to various factors, including easy access to information, different levels of education and culture (Dewantho, 2015). Limited information about reproductive health can cause adolescent sexual behavior to lead to negative things. Adolescents need to get correct and responsible information about sexuality and reproductive health. This study was conducted with the aim of testing the family-based youth character education model in the prevention of premarital sexual behavior in rural and urban areas of Jember Regency.

\section{METHOD}

This research trial was conducted in the working area of the Puger Health Center. When the research will be conducted in SeptemberDecember 2020. The sample in this study is adolescents in the working area of Puger Health Center with the criteria for adolescents aged 1719 years.

At the trial stage of the family-based youth character education model in the prevention of premarital sexual behavior, the research was initiated by completing the licensing process for related parties. After that the researchers screened potential respondents. The prospective respondents were given information for consent about the research to be carried out. The willingness of prospective respondents to become 
research respondents was proven by signing the research informed consent.

The researcher began the activity by conducting a pre-test on the respondents using a questionnaire followed by training for respondents about adolescent character education for the prevention of premarital sexual behavior using modules that have been compiled based on the model found in previous studies, after which a posttest was carried out related to the training. For pre-test and post-test, respondents filled out a questionnaire using google form, and training was carried out by delivering material using the zoom application.

RESEARCH RESULT

Respondent Characteristics

Table 1.Frequency distribution of general data on adolescents as training participants $(\mathbf{n}=30)$

\begin{tabular}{|l|l|l|}
\hline \multicolumn{1}{|c|}{ Category } & \multicolumn{2}{c|}{ Total } \\
\hline Age & \multicolumn{2}{|c|}{ Percentage } \\
\hline 16 & 14 & 46,6 \\
\hline 17 & 16 & 53,4 \\
\hline Total & 30 & 100 \\
\hline Gender & & \\
\hline Male & 12 & 40 \\
\hline Female & 18 & 60 \\
\hline Total & 30 & 100 \\
\hline Religion & & \\
\hline Islam & 25 & 83,3 \\
\hline Catholic & 2 & 6,7 \\
\hline Christian & 3 & 10 \\
\hline Total & 30 & 100 \\
\hline Ever been dating or not & & \\
\hline Not & 13 & 43,3 \\
\hline Yes & 17 & 56,7 \\
\hline Total & 30 & 100 \\
\hline Currently dating & & \\
\hline Not & 14 & 46,7 \\
\hline Yes & 16 & 53,3 \\
\hline Total & 30 & 100 \\
\hline & & \\
\hline
\end{tabular}

Based on the characteristics of the respondents as training participants, it is known that most of the respondents were 17 years old $(53.4 \%)$ with the gender of most of them female $(60 \%)$, most of them are Muslim (83.3\%), most of them have been dating $(56.7 \%) . \%)$, most of them are currently dating (53.3\%).

Changes in Knowledge with Intervention Model of Youth Character Education in Prevention of Premarital Sexual Behavior in
Jember Regency

1. Personal Teens in Prevention of Premarital Sexual Behavior

Adolescent personal knowledge (academic) in the prevention of premarital sexual behavior was assessed based on filling out a questionnaire by the respondent before and after the implementation of the training "Youth Character Education in Prevention of Premarital Sexual Behavior". The results showed that the 
majority of adolescent personal scores increased (93.3\%). The personal score of adolescents based on the questionnaire shows that not all respondents (a total of 30 respondents) experienced an increase in scores, there were 2 respondents who experienced a decrease in scores.

Table 2 Distribution of adolescent personal pre-test and post-test scores in the prevention of premarital sexual behavior

\begin{tabular}{|c|c|c|c|c|c|c|c|c|c|}
\hline \multirow{2}{*}{\multicolumn{2}{|c|}{$\begin{array}{c}\text { Changes in Pre Test \& Post Test } \\
\text { Scores }\end{array}$}} & \multicolumn{2}{|c|}{ Decrease } & \multicolumn{2}{|c|}{ Кeep } & \multicolumn{3}{|c|}{ Increasing Total } & \multirow[t]{2}{*}{$\%$} \\
\hline & & f & $\%$ & $\mathbf{f}$ & $\%$ & f & $\%$ & & \\
\hline \multirow{10}{*}{$\begin{array}{l}\text { Youth } \\
\text { personal }\end{array}$} & Biology & 2 & 6,7 & 0 & 0,00 & 28 & 93,3 & 30 & 10 \\
\hline & & & & & & & & & 10 \\
\hline & Academic & 1 & 3,4 & 0 & 0,00 & 29 & 96,6 & 30 & 10 \\
\hline & & & & & & & & & 0 \\
\hline & Social & 3 & 10 & 1 & 3,4 & 26 & 86,6 & 30 & 10 \\
\hline & Understanding & & & & & & & & 0 \\
\hline & $\begin{array}{l}\text { Friends of the } \\
\text { same age }\end{array}$ & 1 & 3,4 & 0 & 0.00 & 29 & 96,6 & 30 & $\begin{array}{l}10 \\
0\end{array}$ \\
\hline & Sexual Experience & 2 & 3,4 & 0 & 0,00 & 29 & 96,6 & 30 & 10 \\
\hline & & & & & & & & & 0 \\
\hline & Youth personal & 2 & 6,7 & $\mathbf{0}$ & 0,00 & 28 & 93,3 & 30 & $\begin{array}{l}10 \\
0\end{array}$ \\
\hline
\end{tabular}

Statistical analysis was carried out to determine differences in the effects of youth character education training on adolescent personal scores on respondents before and after training. The results of statistical analysis showed the mean score of the post test (after training). Greater (mean $=80.92)$ compared to the pre-test mean (before training) with a mean $=68.23$. This is reinforced by the results of statistical analysis with the $t$ test showing significant differences before and after training. Adolescent character education training is significantly $(\mathrm{sig}=0,000)$ able to increase knowledge of adolescent personalities in preventing premarital sexual behavior. Based on the five indicators of adolescent personal knowledge, it is known that the significant difference in increasing adolescent personal knowledge in the prevention of premarital sexual behavior is in academic factors $(\mathrm{sig}=0.006)$ and peer factors $(\operatorname{sig}=0.002)$.

Table 3 Results of descriptive statistical analysis and paired $T$ test of adolescent personal variables in the prevention of premarital sexual behavior

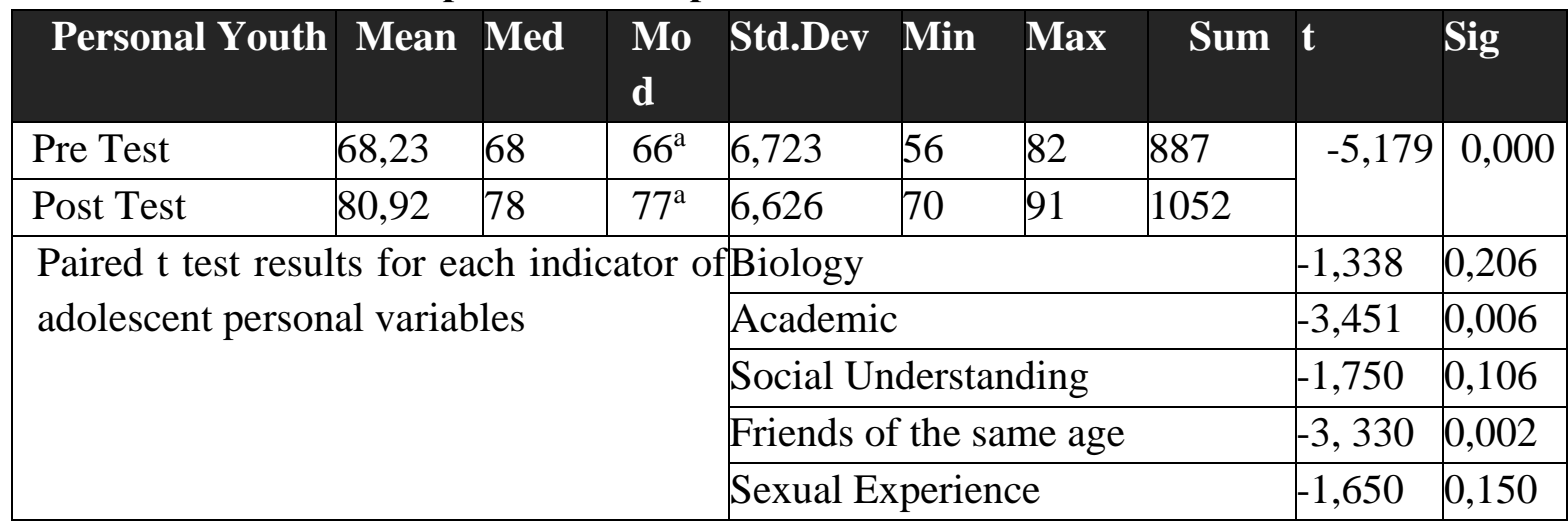




\section{Youth Morality in Prevention of Premarital Sexual Behavior}

Assessment of scores before and after youth character education training is also carried out to assess adolescent morality in efforts to prevent premarital sexual behavior. Based on the data, the score of adolescent morality in preventing premarital sexual behavior is assessed based on filling out a questionnaire by respondent before and after the implementation of the training
"Youth Character Education in Prevention of Premarital Sexual Behavior". The results showed that the majority of adolescent personal scores increased (93.3\%). The youth morality score based on the questionnaire shows that not all respondents (a total of 30 respondents) experienced an increase in scores, there were 2 respondents who experienced a decrease in their scores.

Table 4 Distribution of the pre-test and post-test scores of adolescent morality

\begin{tabular}{|c|c|c|c|c|c|c|c|c|c|}
\hline \multirow{2}{*}{\multicolumn{2}{|c|}{$\begin{array}{c}\text { Changes in Pre Test \& Post Test } \\
\text { Scores }\end{array}$}} & \multicolumn{2}{|c|}{ Decrease } & \multicolumn{2}{|c|}{ Кеep } & \multicolumn{3}{|c|}{ Increasing Total } & \multirow[t]{2}{*}{$\%$} \\
\hline & & f & $\%$ & $\mathbf{f}$ & $\%$ & $\mathbf{f}$ & $\%$ & & \\
\hline \multirow{7}{*}{$\begin{array}{l}\text { Youth } \\
\text { Morality }\end{array}$} & Conscience & 1 & 3,4 & 0 & 0,00 & 29 & 96,6 & 30 & 100 \\
\hline & Pride & 2 & 6,7 & 0 & 0,00 & 28 & 93,3 & 30 & 100 \\
\hline & Empathy & 3 & 10 & 1 & 3,4 & 26 & 86,6 & 30 & 100 \\
\hline & $\begin{array}{l}\text { Kindness } \\
\text { Love }\end{array}$ & 2 & 6,7 & 1 & 3,4 & 27 & 90 & 30 & 100 \\
\hline & Self control & 1 & 3,4 & 1 & 3,4 & 28 & 93,3 & 30 & 100 \\
\hline & Humble & 2 & 6,7 & 0 & 0,00 & 28 & 93,3 & 30 & 100 \\
\hline & $\begin{array}{l}\text { Youth } \\
\text { Morality }\end{array}$ & 2 & 6,7 & $\mathbf{0}$ & $\mathbf{0 , 0 0}$ & 28 & 93,3 & 30 & 100 \\
\hline
\end{tabular}

Statistical analysis was carried out to determine the differences in the effects of youth character education training on adolescent morality scores on respondents before and after training. The results of statistical analysis showed that the mean post test (after training) score was greater $($ mean $=80.69$ ) than the pre-test mean score (before training) with a mean $=78.08$. This is reinforced by the results of statistical analysis with the $t$ test showing significant differences before and after training.
Adolescent character education training significantly ( $\operatorname{sig}=0.002$ ) is able to improve adolescent morality in preventing premarital sexual behavior based on the six indicators of adolescent morality, it is known that the significant difference in increasing adolescent morality in preventing premarital sexual behavior is in the conscience factor $(\mathrm{sig}=0.002)$ and self-control factors. ( $\operatorname{sig}=$ 0.008).

Table 5 Results of descriptive statistical analysis and paired $T$ test for the morality of adolescents in the prevention of premarital sexual behavior

\begin{tabular}{|c|c|c|c|c|c|c|c|c|c|}
\hline Youth Morality & Mean & Med & $\begin{array}{l}\text { Mo } \\
\text { d }\end{array}$ & Std.Dev & Min & $\operatorname{Max}$ & Sum & $\mathbf{t}$ & Sig \\
\hline Pre Test & 78,08 & 77 & 75 & 9,305 & 56 & 82 & 887 & \multirow[t]{2}{*}{$-3,906$} & \multirow[t]{2}{*}{0,002} \\
\hline Post Test & 85,69 & 86 & $84^{\mathrm{a}}$ & 9,375 & 70 & 91 & 1052 & & \\
\hline \multirow{3}{*}{\multicolumn{4}{|c|}{$\begin{array}{l}\text { Paired t test results for each indicator of } \\
\text { the adolescent morality variable }\end{array}$}} & \multirow{2}{*}{\multicolumn{4}{|c|}{$\begin{array}{l}\text { Conscience } \\
\text { Pride } \\
\end{array}$}} & $-3,345$ & 0,002 \\
\hline & & & & & & & & $-1,650$ & 0,120 \\
\hline & & & & \multicolumn{4}{|l|}{ Empathy } & $-1,330$ & 0,125 \\
\hline
\end{tabular}




\begin{tabular}{|l|l|r|r|}
\hline \multirow{2}{*}{} & Kindness Love & $-1,560$ & 0,167 \\
\cline { 2 - 4 } & Self control & $-3,560$ & 0,008 \\
\cline { 2 - 4 } & Humble & $-1,750$ & 0,207 \\
\hline
\end{tabular}

\section{Prevention of Premarital Sexual Behavior}

Prevention of premarital sexual behavior was assessed based on filling out a questionnaire by the respondent before and after the implementation of the training "Youth Character Education in Prevention of Premarital Sexual Behavior". The results showed that most of the pre-marital sexual behavior prevention scores increased (93.3\%). The score for the prevention of premarital sexual behavior based on the questionnaire shows that not all respondents (a total of 30 respondents) experienced an increase in score, there were 2 respondents who experienced a decrease in score.

Table 6 Distribution of pre-test and post-test scores for the prevention of premarital sexual behavior

\begin{tabular}{|c|c|c|c|c|c|c|c|c|c|}
\hline \multirow{2}{*}{\multicolumn{2}{|c|}{ Changes Skor Pre Test \& Post Test }} & \multicolumn{2}{|c|}{$\begin{array}{l}\text { Decreas } \\
\text { e }\end{array}$} & \multicolumn{2}{|c|}{ Keep } & \multicolumn{2}{|c|}{$\begin{array}{l}\text { Increasi } \\
\text { ng }\end{array}$} & \multirow[t]{2}{*}{ Total } & \multirow[t]{2}{*}{$\%$} \\
\hline & & $\mathbf{f}$ & $\%$ & $\mathbf{f}$ & $\%$ & f & $\%$ & & \\
\hline \multirow{6}{*}{$\begin{array}{l}\text { Prevention of } \\
\text { Premarital } \\
\text { Sexual Behavior }\end{array}$} & Resisting Skills & & 10 & 0 & 0,00 & 29 & 96,6 & 30 & 100 \\
\hline & \begin{tabular}{|l|} 
Increase \\
Religiosity
\end{tabular} & 3 & 3,4 & 0 & 0,00 & 27 & 90 & 30 & 100 \\
\hline & $\begin{array}{l}\text { Avoiding } \\
\text { Pornographic } \\
\text { Media }\end{array}$ & & 6,7 & 1 & 3,4 & 27 & 90 & 30 & 100 \\
\hline & $\begin{array}{l}\text { Promotion of } \\
\text { Sexual Health }\end{array}$ & 3 & 10 & 1 & 3,4 & 26 & 86,6 & 30 & 100 \\
\hline & $\begin{array}{l}\text { Improve } \\
\text { Parent-Child } \\
\text { Relationships }\end{array}$ & 1. & 3,4 & 0 & 0,00 & 29 & 96,6 & 30 & 100 \\
\hline & \begin{tabular}{|l|} 
Prevention of \\
Premarital \\
Sexual \\
Behavior \\
\end{tabular} & & 6,7 & $\mathbf{0}$ & $\mathbf{0 , 0 0}$ & 28 & 93,3 & 30 & 100 \\
\hline
\end{tabular}

Statistical analysis was conducted to determine the difference in the effect of youth character education training on the pre-marital sexual behavior prevention score among respondents before and after the training. The results of statistical analysis showed the mean score of the post test (after training). Greater $($ mean $=80.92)$ compared to the pre-test mean (before training) with a mean = 76.15. This is reinforced by the results of statistical analysis with the $t$ test showing significant differences before and after training. Adolescent character education training significantly ( $\mathrm{sig}=$ 0.006) is able to improve the prevention of premarital sexual behavior based on the five indicators of adolescent personal knowledge, it is known that the significant difference in increasing personal knowledge of adolescents in preventing premarital sexual behavior is in the factor of refusal skills $(\operatorname{sig}=0.005)$ and the factor of increasing relationship parent-child $(\mathrm{sig}=0.004)$. 


\section{premarital sexual behavior}

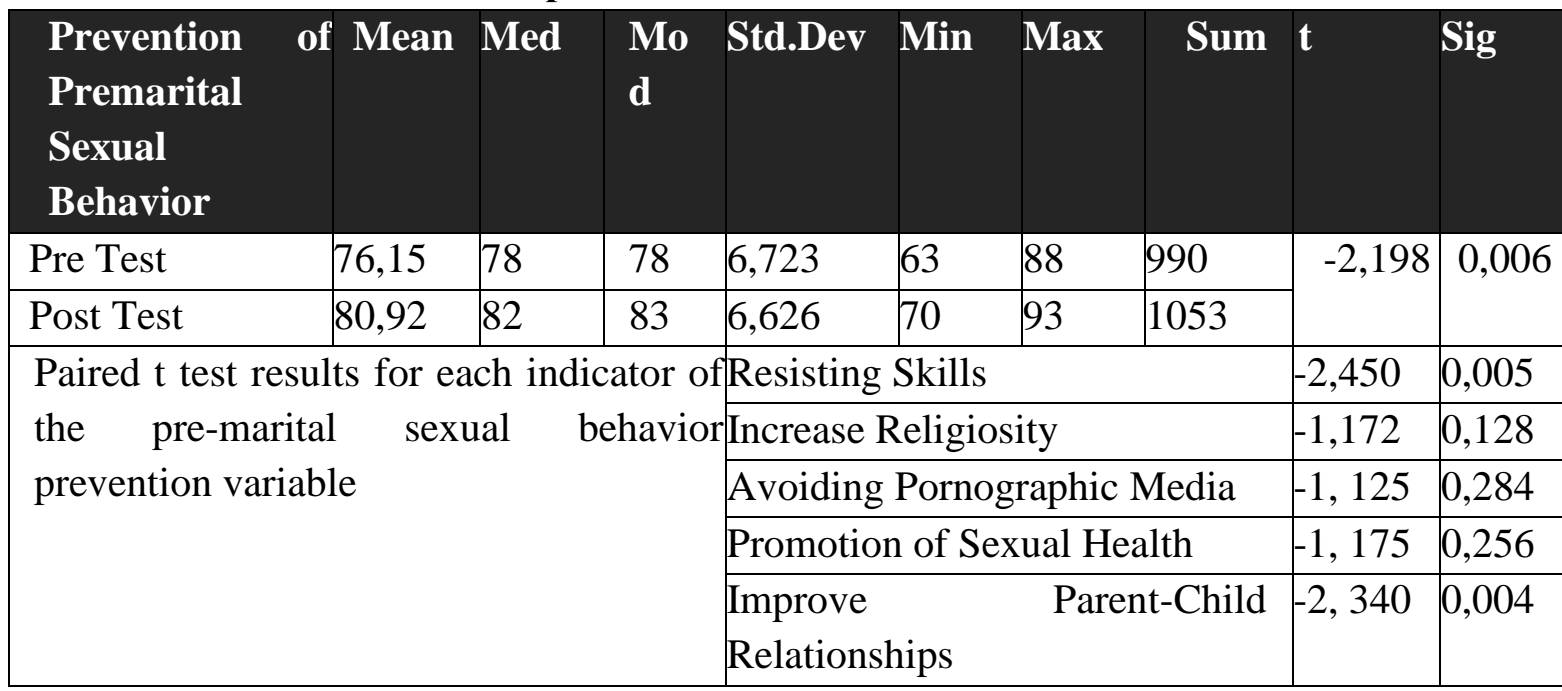

\section{DISCUSSION}

The trial assessment of the intervention model based on the theory that has been built in previous research is measured through pre-training assessments and post-training assessments. Overall the mean score after training showed a higher score than the mean before training. This value is intended for all research variables studied, namely: 1). Adolescent personal knowledge in preventing premarital sexual behavior, 2). Knowledge of adolescent morality in preventing premarital sexual behavior, 3). prevention of premarital sexual behavior.

Based on the results of the statistical analysis of the score of adolescent personal knowledge in the prevention of premarital sexual behavior as a whole before and after training showed a significant increase, namely the academic and peer factors had a significant increase in the prevention of premarital sexual behavior.

Adolescence is an important period in terms of achievement. This is in accordance with the statement of Henderson and Dweck (in Santrock John W, 2013) which states that adolescence is an important period in terms of achievement. Social and academic pressures push adolescents to the roles that adolescents must carry out. A role that often demands greater responsibility. Achievement is very important for teenagers and teenagers begin to realize that at this time they are required to face the real life.

According to Istiadi (2019) it is necessary to have the competence of adolescent attitudes as follows. 1) Clarity of goals to be achieved because the clearer a goal is, it will be able to lead to a consistent attitude even though there are many obstacles that arise on the way. 2) Have a strong intention to achieve goals. Intention or impulse will make teenagers continue to do what teenagers believe in that intention. The impulse of the heart to pursue a dream that will automatically discipline itself, so that it continues to work towards that dream. 3) Determination of priority scale. A person who has a strong desire to achieve his dreams must choose an attitude selectively and not take his time carelessly. 4) Diligent and patient in achieving the believed success. Youth as the next generation of the ideals of the nation's struggle, should be more directed and prepared in such a way, so that it truly is a guarantee for the survival of the nation and state and has high religious values, so that the energy in adolescents is diverted to positive things and avoid premarital sexual behavior.

Based on the theory of psychological development, adolescence is a transitional period and there is a shift in the influence of family to peer. This is due to an increase in the interest of adolescents in engaging in friendly relations and participation in groups. According to Nasution, adolescents will gain various experiences from 
these interactions, one of which is the experience of dealing with the opposite sex or other matters related to sexuality. Most adolescents feel that discussing sexuality with peers will be more fun than telling stories with parents. If the negative influence from peers is greater than the resistance in adolescents, then adolescents tend to be affected because adolescents want acceptance in the group even though this is contrary to the teachings of their parents (Sarwono, 2012).

The influence of the group (peers) is very influential in adolescent premarital sexual behavior and is an effort to become part of the group by following the norms that have been adopted by the group (pre-marital sexual behavior). In addition, they are driven by a great curiosity to try all unknown things (Azwar, 2015). They are also not fully aware of the premarital sexual behavior of adolescents because in the teenage phase, they generally have a very strong sexual urge, while the risks due to sexual activity that lead to sexual intercourse are not fully known (Surbakti, 2019). Teens consider their peers as something important. Adolescents consider their peer group to provide a world where adolescents begin to socialize, the values that apply are not the values set by adults but by their friends (Susanti, 2018).

Based on the results of statistical analysis of the score of adolescent morality knowledge in the prevention of premarital sexual behavior as a whole before and after training showed a significant increase, namely the conscience and self-control factors had a significant increase in the prevention of premarital sexual behavior.

Premarital sexual behavior is related to the morals and norms that apply in society. According to Sarwono (2013) norms act as a social control mechanism that will reduce the likelihood of a person engaging in premarital sexual behavior outside the boundaries of religious provisions. The results showed that there was a significant relationship between self-control and premarital sexual behavior, the higher the self-control of a teenager, the lower the adolescent premarital sexual behavior that appeared, on the contrary, the lower the self-control of a teenager, the higher the premarital sexual behavior. emerging. According to Mesina and Gunarsa (in Khairunnisa, 2013). Self control serves to limit individuals to behave negatively. Individuals who have self-control will avoid various negative behaviors and premarital sexual behavior.

Based on the results of statistical analysis on the overall knowledge score of pre-marital sexual behavior prevention before and after the training showed a significant increase, namely the skills to resist negative pressure and fostering relationships between parents and children had a significant increase in the prevention of premarital sexual behavior.

The role of parents is very important in guiding adolescents so that they can practice the skills to resist negative peer pressure with assertive training. Assertive training is a behavior training program to train someone to convey their needs, rights, and make choices without hurting the rights of others (Wahyuningsih, 2019). Adolescents who have an assertive attitude are able to state what they think, feel and are able to deal with peer pressure, besides that what is more important in this study is that adolescents are able to firmly reject various kinds of irrational invitations, such as having sex before marriage.

Moeliono and Laurike, (2016) being assertive (assertive) is a special way that can be learned and practiced which enables a person to be able to express what they think, feel, and assess openly, directly, while respecting the feelings and rights of others. Esti (2015) in his research states that the goal of assertive training is to improve interpersonal skills, namely adolescents are able to say "no", make requests, and express feelings both positive and negative.

The benefits of assertive training for adolescents are that adolescents are able to act assertively, what is meant here is that adolescents have principles in their lives. An individual who has principles in his life, will not waver, and is able to control himself. The principles possessed by an individual are reinforced by the power of faith. The prevailing religious norms prohibit sexual intercourse before marriage (Nurhayati, 2011). 
Fallah's research (2019) explains that assertive behavior in adolescents regarding premarital sexual behavior is the ability of adolescents to be firm in defending their sexual rights not to be harassed, to distinguish good and bad behavior, and to make sexual decisions, while still respecting peer rights and without hurting. friends of the same age.

According to Gunarsa, 2010 states that premarital sexual behavior among adolescents can be caused by environmental factors, both the family environment and the social environment. The family environment in question is whether or not the religious education provided by the parents is sufficient, the love and attention the child receives from the family is not sufficient, and the role model the child receives from the parents is not sufficient. If not, then the child will look for a place to escape on the streets and in places that do not educate them, the child will be raised in an environment that is not healthy for their mental growth, and the child will grow up in an environment of promiscuity. The social environment in question is an environment outside the family, namely the influence of peers and the mass media. Peers (peer groups) also play a very strong role in adolescent sexual attitudes and behavior (Zastrow and Kirt-Ashman, 2012).

Teenagers are more outside the home with peers, so that the attitudes, conversations, interests, appearance and behavior of peers have a greater influence than family, for example, if a group member tries to date, then adolescents tend to follow regardless of the consequences. In the peer group, adolescents try to find themselves, adolescents are judged by their peers regardless of the sanctions of the adult world. Peer groups provide an environment that is a world where teenagers can socialize where the prevailing values are not the values set by adults but by their peers (Gunarsa, 2010).

Based on this, it is dangerous for the mental development of adolescents, if the values developed in the peer group are negative values, it will be more dangerous if this peer group tends to be closed (closed group), each member cannot be separated from the group and must follow the values developed. by the group leader, the attitude, thoughts, behavior and lifestyle are the behavior and lifestyle of the group. The interaction between peers can predict the intention variable of premarital sexual behavior. This opinion is emphasized by BKKBN (2010) that three times the factors that most influence adolescents to engage in premarital sexual behavior are: 1) Peers have a boyfriend, 2) Have friends who agree with premarital sexual behavior, 3) Have friends who influence or encourage to engage in premarital sexual behavior.

Adolescents feel lonely and uncomfortable in the family and community environment, sociological theory calls it a life that is "hurry-busy and lonely crowd" (lonely in a crowd), but the life of adolescents in the mass media environment and peer groups of teenagers feel happy and really enjoy. where according to organizational theory is said to be the System Dynamics, namely "establishing relationships and connected" (connected and unified). This makes adolescents look for peer group environments that provide peace and pleasure, with peer groups between adolescents communicating with each other and confide in each other and even exchange experiences about everything that is read and seen on websites and other information media. The relationship between peer groups in adolescent life is becoming increasingly free. This causes adolescents to have a high risk of premarital sexual behavior. Based on this, it is necessary to have a good relationship between parents and adolescents so that parents can be used as friends to tell stories or communicate about all things, so that they can avoid premarital sexual behavior.

\section{Conclusion}

Based on this discussion, from the model trial in rural areas by conducting character education model training for adolescents, it is proven to be able to increase adolescent personal knowledge, adolescent morality and prevention of premarital sexual behavior. Therefore the next recommendation is suggested to try out the youth 
character education model in urban areas in Jember Regency.

\section{Reference}

[1] Azwar. (2015) Sikap manusia teori dan pengukurannya. Edisi 2, Pustaka Pelajar, Jogjakarta

[2] Amirulloh. (2015) Teori pendidikan karakter remaja dalam keluarga, Alfabeta, Bandung

[3] BKKBN (2010) Pendalaman materi membantu remaja memahami dirinya, Direktorat Remaja dan Perlindungan Hakhak Reproduksi, Jakarta

[4] Depkes R.I . (2007) Kesehatan reproduksi remaja (KRR), buku saku untuk remaja usia 14-19 Tahun. Kanwil. Depkes, Surabaya

[5] Donna, H. (2014) Consequences of Parenting on Adolescent Outcomes, Societies, Vol.4, pp.506-531.

[6] Friedman, M.M. (2003) Buku ajar keperawatan keluarga : riset, teori, EGC, Jakarta

[7] Fallah. 2019. Hubungan antara perilaku asertif dengan perilaku seksual pranikah pada remaja putri. [serial online]. http://etd.eprints.ums.ac.id/4793/1/F10004 0046.PDF

[8] Gunarsa, D.,S. aja, Gunung Mulia, Jakarta (2010) Psikologi Perkembangan Anak dan Remaja

[9] Istiadi (2019) Mengenali permasalahan perkembangan anak usia remaja, Direktorat Jenderal Pendidikan Tinggi, Jakarta

[10] Khairunnisa, (2013) Hubungan religiusitas dan kontrol diri dengan perilaku seksual pranikah remaja di MAN 1 Samarinda, Jurnal Psikologi, Vol.1, No. 2, pp :220229.

[11] Leeuwen, K.G. V., Marvielde, I., Braet, C., Bosmans, G. (2014) Child Personality and Parental Behavior as Moderators of Problem Behavior: Variable and PersonCentered Approaches, Developmental Psychology, Vol. 40, No. 6, pp. 1028-1046.
[12] Lickona, T. (1992) Educating for character: How our schools can respect and responsibility, Bantam Books, New York (2013) Educating for character in the sexual domain. Peabody journal of education, Vo. 88. Pp. 198-211. (2013) Educating for character (mendidik untuk membentuk karakter). Terj. oleh Juma Abdu Wamaungo, Bumi Aksara, Jakarta

[15] Lickona, T., Schaps, E., \& Lewis, C. (2003) CEP's Eleven principles of effective character education, DC: Character Education Partnership, Washington

[16] Mubarak, W. (2012) Ilmu kesehatan masyarakat konsep dan aplikasi, Salemba, Jakarta

[17] Mu'tadin (2012) Pendidikan islam di rumah, sekolah dan masyarakat, Gema Insani Press, Jakarta

[18] Moeliono, L. 2016. Proses belajar aktif: Komunikasi, informasi \& edukasi (KIE) kesehatan reproduksi remaja bagi anak usia 11-15 tahun (kelompok pramuka penggalang), Perkumpulan Keluarga Berencana Indonesia (PKBI), Badan Koordinasi Keluarga Berencana Nasional (BKKBN), dan United Nations Population Fund (UNFPA), Jakarta

[19] Nurhayati. (2011) Hubungan pola peran, komunikasi, nilai dan norma keluarga dengan perilaku seksual remaja sekolah lanjutan tingkat atas di Kabupaten Bekasi." Tidak diterbitkan. Tesis, Program Studi Magister Ilmu Keperawatan, Universitas Indonesia.

[20] Overbeek, G., Vollebergh, W. A. M., Engels, R. C. M. E., Meeus, W. H. J. (2013) Parental Attachment and Romantic Relationships: Links With Emotional Disturbance During Late Adolescence, Journal of Counseling Psychology, Vol. 50, pp. 28-39.

[21] Susanto, T., Rahmawati, I., Wantiyah (2016) A Community-Based Friendly Health Clinic: An Initiative Adolescent 
Reproductive Health Project in The Rural and Urban Areas of Indonesia, International Journal of Nursing Sciences. Vol. 3, pp. 371-380.

[22] Suyatno. (2012) Urgensi pendidikan karakter, Kompas, Jakarta

[23] Simanjuntak (2019) Membangun disiplin diri melalui kecerdasan spritual dan emosional, Batavia Pers, Yogyakarta

[24] Sarwono S W. (2005) Psikologi remaja, PT Raja Grafindo Persada, Jakarta

[25] (2010) Psikologi remaja. Edisi revisi cetakan 14, PT.Rajawali Grafindo Persada, Jakarta

[26] (2013). Psikologi remaja, PT Raja Grafindo Persada, Jakarta

[27] Soetjiningsih. (2005) Tumbuh kembang anak, EGC, Jakarta

[28] Soetjiningsih, Ranuh, Suraatmaja, Rusmil, Pangkahila, Fadlyana. (2008) Buku ajar tumbuh kembang remaja dan permasalahannya, Sagung Seto, Jakarta

[29] Soetjiningsih, C.,H. (2007) Faktor-faktor yang mempengaruhi perilaku seksual remaja pranikah. Disertasi, Program Pendidikan Doktor Psikologi UGM, Yogyakarta

[30] Surbakti, E.B. 2019. Kenakalan orang tua penyebab kenakalan remaja, Elex Media Komputindo, Jakarta

[31] Susanti, F. 2018. Menuju masa akhil baligh, Sunda Kelapa Pustaka, Jakarta

[32] Sarwono S W. (2013) Psikologi remaja, PT Raja Grafindo Persada, Jakarta

[33] Zastrow, C.H. dan Kirst-Ashman, K. (2012) Understanding human behavior and the social environment, Sixth ed, CA: Brooks/Cole, Belmont 